\title{
Nevyriausybinių organizacijų ir savivaldybių sąveika Lietuvoje: teoriniai sprendimų priẻmimo ir igyvendinimo proceso aspektai
}

\author{
Aušra Šilinskytė \\ Mykolo Romerio universitetas \\ Valakupiu g. 5, LT-10101 Vilnius \\ DOI:10.13165/VPA-15-14-2-05
}

\begin{abstract}
Anotacija. Straipsnyje analizuojama, kokie veiksniai daro poveiki nevyriausybiniu organizaciju galimybèms dalyvauti sprendimu priemimo ir igyvendinimo procese savivaldybès lygmeniu Lietuvoje. Pirmoje darbo dalyje siekiama išanalizuoti pilietinès visuomenès ir nevyriausybiniu organizaciju tarpusavio santyki bei ju galimus vaidmenis ir poveiki viešajam sektoriui. Antrojoje darbo dalyje struktūrizuojamas sprendimu priemimo ir igyvendinimo procesas bei išskiriami nevyriausybiniu organizaciju dalyvavimo sprendimu priemimo ir igyvendinimo savivaldybèse proceso komponentai, kuriais remiantis siekiama numatyti nevyriausybiniu organizaciju dalyvavimo savivaldybiu sprendimu prièmimo ir igyvendinimo procese galimybes bei jiems poveiki darančius veiksnius.
\end{abstract}

Raktažodžiai: nevyriausybinès organizacijos, pilietine visuomené, savivaldybè, sprendimu priemimo procesas.

Keywords: non-governmental organizations, civil society, municipality, decisionmaking process.

\section{İvadas}

Viešojo valdymo transformacijų laikotarpiu, igalinant piliečius ir ịtraukiant juos i sprendimų prièmimo procesą, skatinamas nevyriausybinių organizacijų vaidmens ir jų turimų galių nuolatinis augimas. Šių organizacijų vaidmuo ir sąveika su viešuoju sektoriumi Lietuvoje ịprastai tiriama jų galimo tarpusavio bendradarbiavimo skatinimo klausimais, tačiau bendradarbiavimo analizė apsiriboja viešujų paslaugų teikimo bei finansinès paramos šiam sektoriui analize $[5,6,24,7,15]$. Nors Nevyriausybinių 
organizacijų informacijos ir paramos centro (NISC) iniciatyva nuo $2012 \mathrm{~m}$. buvo atlikti tyrimai, apimantys platesnius NVO sektoriaus tyrimus, taip pat nagrinèti šio sektoriaus valdymo ir dalyvavimo aspektai, tačiau šių sektorių sąveika, dalyvaujant bei darant poveikį vietos savivaldos viešujų reikalų tvarkymui, nagrinejjama tik esamo bendradarbiavimo identifikavimo aspektu neanalizuojant skirtingų sąveikos galimybių.

Lietuvoje nevyriausybinių organizacijų dalyvavimas priimant bei įgyvendinant sprendimus, ịprastai yra tiriamas bendrame pilietinès visuomenès arba bendrame visų suinteresuotų grupių kontekste $[1,28,8]$, neišskiriant šių organizacijų veiklos specifikos ar galimų jų dalyvavimo priimant ir ịgyvendinant sprendimus mechanizmų, todèl šiame straipsnyje nevyriausybinès organizacijos analizuojamos kaip pilietinès visuomenès veiklos išraiška, siekiant atskleisti šio sektoriaus veiklos išskirtinumą bei dalyvavimo priimant ir igyvendinant sprendimus galimybes.

Tikslas: nustatyti, kokie veiksniai daro poveikị nevyriausybinių organizacijų dalyvavimo sprendimų prièmimo ir ịgyvendinimo procese galimybėms savivaldybės lygmeniu Lietuvoje.

Uz̆daviniai: išanalizuoti pilietinès visuomenès ir nevyriausybinių organizacijų vaidmeni Lietuvoje; struktūrizuoti sprendimų prièmimo ir ịgyvendinimo procesą savivaldybėse; numatyti nevyriausybinių organizacijų dalyvavimo savivaldybių sprendimų prièmimo ir ịgyvendinimo procese galimybes bei joms poveikị darančius veiksnius.

Analizuojant nevyriausybinių organizacijų dalyvavimo sprendimų prièmimo procese teorinius aspektus, taikomi mokslinès literatūros analizès, sintezės, lyginamosios analizès, logografijos bei apibendrinimo metodai.

\section{NVO ir pilietinės visuomenės poveikis viešajam sektoriui}

Nevyriausybinių organizacijų vaidmuo tarptautiniu lygmeniu dažniausia nagrinejjamas kalbant apie pagalbos trečiosioms šalims organizacijų veiklą, tuo tarpu nagrinejjant šias organizacijas atskirose kontinentinès Europos bei anglosaksų šalyse, akcentuojamos šioms organizacijoms priskiriamos funkcijos ir bandomas apibréžti nevyriausybinių organizacijų sąvokos turinys. Nagrinèjant jų poveikị viešajam sektoriui, visu pirma išskirtina, jog pilietinès visuomenès sąvoka gali būti vertinama dvejopai: normatyviniu požiūriu ši sąvoka daro poveiki piliečių ir socialiniu grupių motyvavimui ir mobilizavimui viešai politinei veiklai, o institucinis pilietinès visuomenès aspektas akcentuoja piliečių subjektiškumą, jų kuriamą autonominių visuomeninių institutų tinklą, išreiškiantị piliečių savanorišką susitarimą, jų saviraidos siekị $[28$, p. 26]. Pilietiné visuomené plačiaja prasme taip pat dažnai tapatinama su trečiojo sektoriaus segmentu, apimančiu visas gyventojų iniciatyva veikiančias organizacijas, draugijas ir socialinius judejjimus, tačiau kalbant apie nevyriausybines organizacijas, kaip pilietinès visuomenès išraišką, pabrèžtina, jog pilietine visuomene ir jos dalimi gali būti laikomi ne tik piliečiai, bet ir užsieniečiai ar juridiniai asmenys, 
tad šioms organizacijoms apibrèžti Lietuvoje ịprastai vartojama nevyriausybinių organizacijų sąvoka.

Nevyriausybinių organizacijų plètros įstatyme teigiama, jog nevyriausybinès organizacijos - tai nepolitinis, nereliginis ir ne pelno siekiantis pilietinès visuomenès darinys, turintis patvirtintą struktūrą, procesus, apibrèžtas funkcijas bei skirtas atstovauti visuomenès ar atskiros jos grupès interesams, sąveikaujantis su kitomis interesų grupèmis (kitomis nevyriausybinėmis organizacijomis, privačiu sektoriumi, viešuoju sektoriumi) [19], tačiau, kaip nurodo S. Mačiukaitė-Žvinienè, J. Grigaliūnaitè, nors jų gausa yra vienas esminių atviros pilietinès visuomenès bruožų, bet jų plètra ir veiklos skatinimas ne visada tapatus pilietinès visuomenès aktyvumo augimui ir plètrai [14, p. 115-116]. Pagrindiné tam poveikị daranti priežastis yra tai, jog pilietinè visuomenė yra suvokiama ne kaip atskiras sektorius, bet kaip ryšys tarp skirtingu sektorių (1 pav.).

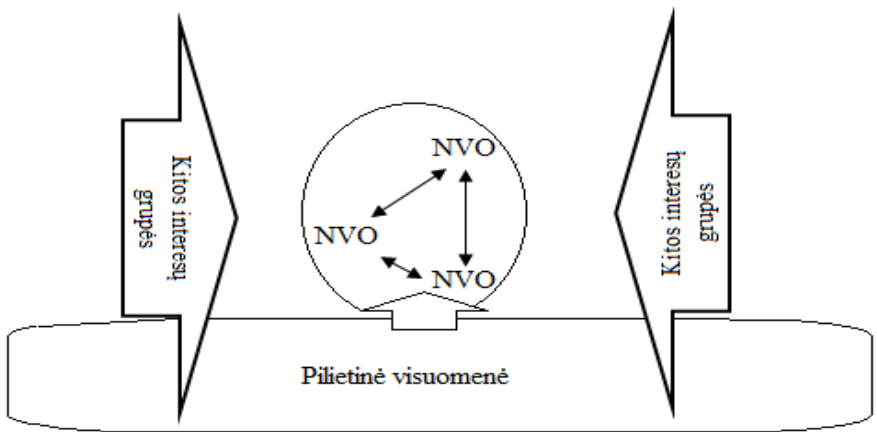

\section{1 pav. Nevyriausybinių organizacijų ir pilietinès visuomenės sąveika}

Šaltinis: sudaryta autorès

Piliečių dalyvavimą valstybės lygmeniu plačiaja prasme galima skirstyti pagal kelias pagrindines kategorijas, tai yra piliečių itraukimas, piliečių veikla (pvz., lobizmas, protestai ir pan.), dalyvavimas rinkimuose ir prievolès (pvz., mokesčių mokèjimas) [27, p. 87], tačiau šiame straipsnyje, nagrinėjant nevyriausybinių organizacijų ir savivaldybių sąveiką, nagrinèjami tik du pirmieji aspektai, atsižvelgiant ị piliečių įtraukimą ir jų veiklas per jų interesus atstovaujančias organizacijas.

Kitas svarbus aspektas, jog nagrinėjant šių dienų nevyriausybinių organizacijų veiklą bei santykị su viešuoju sektoriumi, sunku griežtai apibrěžti jų veiklos sritis, todèl išskiriami skirtingi jų veiklos vertinimo ir grupavimo metodai. Vienas dažniausių - jų skirstymas i pasiūlos (paslaugas teikiančias organizacijas) bei paklausos (propagandos ar lobistines organizacijas, siekiančias daryti poveikį viešajai politikai bei viešojo sektoriaus priimamiems sprendimams) nevyriausybines organizacijas [3, p. 24], arba joms priskiriamas vykdytojų, katalizatorių ar partnerių vaidmuo 18, p. 68-69]. Lyginant šio sektoriaus padèti kontinentinès Europos ir anglosaksų 
šalyse H. Millar nurodo, jog pirmiausia jų skirtumams poveikį daro skirtingas jų valdymo tipas: antreprenerinio tipo šalyse (JAV, Jungtinėje Karalysteje bei Kanadoje) decentralizuojant viešųjų paslaugų teikimą ir jị perleidžiant nevalstybinio sektoriaus organizacijoms (tarp jų ir privačioms ar labdaros organizacijoms) išskiriama jų kaip pasiūlos organizacijų svarba bei dèmesys skiriamas paslaugų kokybei, finansavimo mechanizmams tobulinti, jiems audituoti bei monitoringui; kontinentinès Europos šalyse, kur valdymas paremtas horizontaliu tinkliniu valdymu ir visi dalyviai siekia bendrų vertybių ir tikslų, šios organizacijos yra mažiau kontroliuojamos, skirtumus tarp sektorių mažeja ir NVO suteikiamas paklausos nevyriausybinių organizacijų vaidmuo [22]. Šie vykstantys pokyčiai yra vienas iš faktorių, didinančių NVO daromą poveikị ir mažinančių atskirtị tarp jo ir viešojo sektoriaus bei suteikiančių jam išskirtinę padètị, lyginant su kitomis interesų grupèmis.

Lietuvoje, kaip ir kituose postkomunistiniuose kraštuose, kuriuose išsivystė nevyriausybinių organizacijų tinklas, pastebimas perẻjimas nuo įvairiausių visuomenès opozicinių veiksmų prie subtilesnių, t. y. revoliucingas požiūris keičiamas konstruktyviais veiksmais, pereinama prie atskirų visuomenès grupių interesų atstovavimo bei nuo veiksmų, paremtų jëga, pereinama prie veiksmų, paremtų tiesa, naudojantis valdžios mechanizmais [32, p. 60]. Lyginant pilietinès visuomenès ir jų organizacijų padèt Centrinëje ir Rytų Europoje, remiantis 2010-2012 metu pilietinès visuomenès tvarumo indeksu (angl. CSO Sustainability Index), kurio vertinimo kriterijai remiasi ir NVO sektoriaus vertinimu, bei sukurta teisine baze, teikiamomis paslaugomis ir infrastruktūra [10, p. 25], galima išskirti, jog šio sektoriaus padètis Lietuvoje vis dar atsilieka nuo bendro šiaurinès centrinès Europos šalių regiono vidurkio, o nuo pirmaujančių šalių Estijos $(2,00)$ ir Lenkijos $(2,2)$ bendras Lietuvos indeksas $(2,7)$ atsilieka keliomis dešimtosiomis dalimis, tačiau jis ženkliai lenkia likusias šalis bei bendrą Centrinès ir Rytų Europos šalių indeksą, kuris siekia 4,6 balo, tad Lietuva gali būti išskiriama kaip viena daugiausiai dẻmesio pilietinès visuomenès ir nevyriausybinių organizacijų plètrai skiriančių valstybių šiame regione.

Nagrinejjant pilietinès visuomenès ir nevyriausybinių organizacijų, dar dažnai išskiriamų kaip trečiasis sektorius, poveikị, mokslinėje literatūroje dažniausia nagrinejjamas jų kaip paslaugas teikiančiu organizacijų vaidmuo $[5,6,7,24]$, kur šios organizacijos pastaraisiais dešimtmečiais užima vis didesnę rinkos dalị (2 pav.), tačiau tai ne tik skatina jų kaip paslaugų teikejjos vaidmens augimą, bet ir suteikia joms galimybę daryti poveikị sprendimams, kokios paslaugos ir kaip turètų būti teikiamos. 


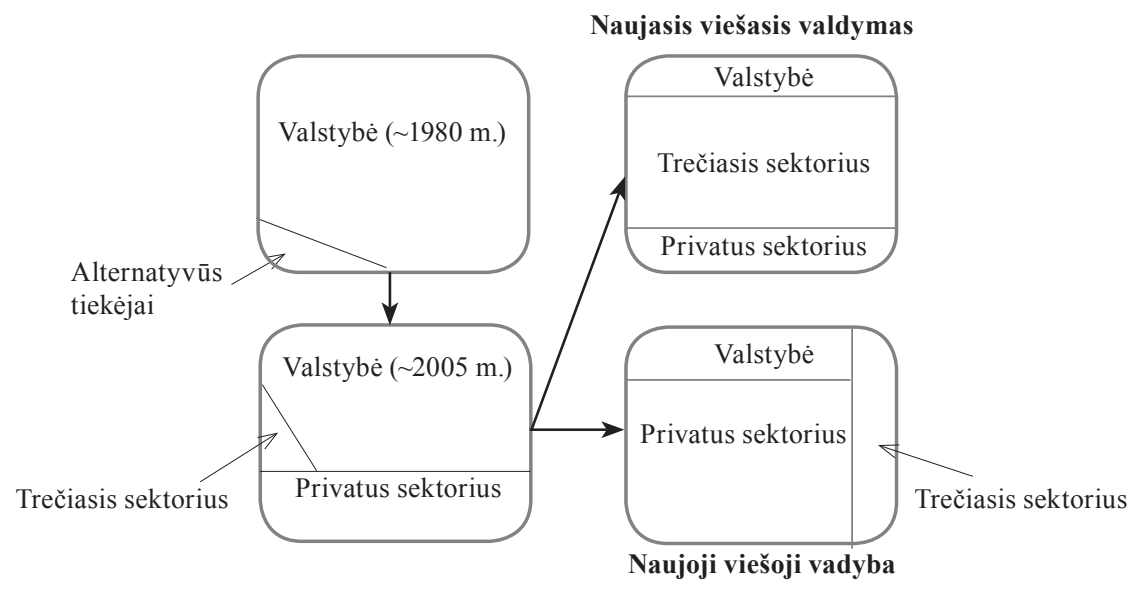

2 pav. Gerovès valstybės raida Europoje 1980-2030 metais

Šaltinis: [24, p. 23]

Remiantis pateikta schema, galima ne tik numatyti tolimesnes nevyriausybinių organizacijų vaidmens viešojo valdymo sistemoje perspektyvas bei jų poveikio gerovès valstybèse augimą, tačiau taip pat tai, jog šios organizacijos, dalyvaudamos teikiant viešąsias paslauga, ne tik perima tam tikras iki tol buvusias valstybinių institucijų veiklas, taip sumažindamos valstybès biudžeto išlaidas, tačiau atitinkamai tampa prieš tai jas teikusių biudžetinių organizacijų ar privataus sektoriaus konkurentais teikiant paslaugas, todèl tai dažnai apsunkina galimą bendradarbiavimą tarp organizacijų ir bendrų veiklų plètojimą.

Pereinant nuo naujosios viešosios vadybos prie naujojo viešojo valdymo principais paremto valdymo ryškejjantis jų, kaip paklausos organizacijų, vaidmuo keičia ir jų veiklos bei poveikio analizès kriterijai. Kaip teigiama [Denhardt \& Denhardt, cit. iš 12, p. 9], „turi būti apsvarstyta ne tik jų dalyvavimas įgyvendinant programas, bet ir augantis jų poveikis iškeliant viešas problemas, pasirenkant politines alternatyvas bei priimant politinius ir administracinius sprendimus". Tuo tarpu kiti autoriai [13, 31] pažymi, jog jų poveikis turètų būti nagrinèjamas dar platesniu aspektu, apimant tai, kaip tinklinèje visuomenejje veikiančios nevyriausybinès organizacijos keičia galios pasiskirstymą tarp piliečių, bendruomenių ir viešojo sektoriaus institucijų ir kokias pasekmes jos sukelia, bei pažymi, jog augant šių organizacijų galiai svarbiu klausimu tampa kieno interesams ir kaip jos atstovauja.

Nagrinėjant nevyriausybinių organizacijų, kaip piliečiams atstovaujančių organizacijų, sąveiką su valdžia ir jos institucijomis, bendradarbiavimo intensyvumas ir formos priklauso nuo daugelio veiksnių: nagrinèjamos šalies ir jos viešojo valdymo tradicijų, bendruomeniškumo ir pilietinès visuomenès aktyvumo, informacijos ir jos sklaidos kanalų intensyvumo ir t. t. Naujojo viešojo valdymo kontekste šią sąveiką galima apibrèžti integruojant S. R. Arnstein suformuotus piliečių įtraukimo lygmenis 
bei S. P. Osborne'o ir K. McLaughlino išskirtus savivaldos institucijų bei bendruomeninių organizacijų ir piliečių sąveikos būdus.

\begin{tabular}{|c|l|}
\hline \multirow{2}{*}{ Piliečių galia: } & 8. Piliečių kontrolė \\
\cline { 2 - 2 } & 7. Deleguotoji galia \\
\cline { 2 - 2 } Simbolinis įtraukimas: & 6. Partnerystė \\
\hline \multirow{3}{*}{ Nedalyvavimas: } & 5. „Nuraminimas“ \\
\cline { 2 - 2 } & 4. Konsultavimas \\
\cline { 2 - 2 } & 3. Informavimas \\
\hline \multirow{2}{*}{ 2. Terapija } \\
\cline { 2 - 2 } & 1. Manipuliacija \\
\hline
\end{tabular}

3 pav. Piliečių ịtraukimo lygmenys

Šaltinis: [2, p. 217]

\begin{tabular}{|c|c|c|c|}
\hline & & \multicolumn{2}{|c|}{ Ko-dalyvavimas (Co-governance) } \\
\hline \multirow{3}{*}{ 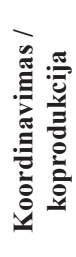 } & & Žemas & Aukštas \\
\hline & 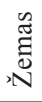 & $\begin{array}{l}\text { Sąveika neegzistuoja } \\
\text { (No relationship) }\end{array}$ & $\begin{array}{c}\text { VP tinklas } \\
\text { (Policy network) }\end{array}$ \\
\hline & 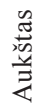 & $\begin{array}{l}\text { Agentūros } \\
\text { (Agency) }\end{array}$ & $\begin{array}{c}\text { Bendruomenés } \\
\text { valdžia } \\
\text { (Community governance) }\end{array}$ \\
\hline
\end{tabular}

4 pav. Vietos valdžios ir savanoriškų bei bendruomeninių organizacijų sąveika

Šaltinis: [23, p. 579]

Šių autorių teigimu, organizacijų igalinimas galimas tik esant tarpusavio pasitikèjimui bei suteikus galių piliečiams bei nevyriausybinėms organizacijoms. Simbolinis piliečių ar jų interesams atstovaujančių institucijų ịtraukimas gali prisidèti prie jų informavimo ir interesų bei požiūrio atskirais klausimais išreiškimo, tačiau nesuteikia priemonių jiems dalyvauti visame sprendimų prièmimo ir igyvendinimo procese bei to, ką autoriai ịvardija kaip „,bendruomenès valdžia“ igyvendinimo. Tokiu atveju dèl informacijos asimetrijos ir netolygaus galių pasiskirstymo nevyriausybinès organizacijos gali būti ịtrauktos tik kaip paslaugų teikèjos arba jų igalinimas išliks tik vienu iš viešojo sektoriaus retorikos elementų.

\section{Nevyriausybinių organizacijų poveikis sprendimų prièmimui ir igyvendinimui vietos savivaldos lygmeniu}

Lietuvoje, nepaisant nevyriausybinių organizacijų vaidmens išaugimo, dalyvavimas priimant bei igyvendinant sprendimus ịprastai tiriamas bendrame pilietinès visuomenės ar suinteresuotų grupių kontekste $[1,8,28]$ ir tik keletas autorių išskyrè šio sektoriaus ịtraukimo ir igalinimo dalyvauti viešajame valdyme savivaldos lygme- 
niu aspektus $[31,32,14,17]$. Valstybės institucijų sprendimai ir jų veiklos rezultatai nebėra organizuojami hierarchinėse sistemose, kaip tradiciniame viešajame administravime, tai ịvairių suinteresuotų subjektų (verslo, nevyriausybinių organizacijų, viešojo sektoriaus organizacijų), susijusių tarpusavyje ,tinkliniais ir horizontaliais ryšiais" padarinys [15, p. 25]. Tarpusavio sąveikai sprendimų prièmimo ir igyvendinimo procese daro poveikị skirtingo lygmens veiksniai, tai yra išoriniai ekonominiai, socialiniai, teisiniai, politiniai ir vidiniai, turintys įtakos atskirų subjektų veiklai. A. Crane'as, analizuodamas tarpsektorinę partnerystę, tai ịvardija kaip „mažasis valdymas" (,small g" governance), kuris apima formalias bendradarbiavimo taisykles ir procedūras, bei „didysis valdymas“(,big G“ governance), analizuojantis aukštesnį visos sistemos valdymą, veiklos būdus, mechanizmus bei keliamus tikslus, igyvendinant visuomenès poreikius [9, p. 17]. Analizuojant šią sąveiką, taip pat atkreiptinas dèmesys, jog šių grupių igalinimas taip pat gali sukelti ir nenorimas pasekmes:

1. suteikiant galimybes dalyvauti priimant sprendimus būtina atsižvelgti ị tai, koks siekiamų priimti sprendimų turinys, kokie sprendimų prièmimo ir atskirų grupių interesų atstovavimo mechanizmai bei kokias pasekmes priimtų sprendimų igyvendinimas gali turèti $[16$, p. 89-90];

2. bet koks siekis imtis reformų ar pakeisti esamą padètị veda prie galimų konfliktų su kitomis suinteresuotomis grupèmis, kurių gerové priklauso nuo esamos padèties išlaikymo $[4$, p. 30].

Lietuvoje, siekiant skatinti šio sektoriaus veiklą vietos savivaldos lygmeniu, NVO atstovai kviečiami ị konsultacijas, įtraukiami ị ịvairių projektų rengimą, darbo grupes, prie savivaldybių tarybų steigiamos NVO tarybos, todèl nagrinėjant šių organizacijų dalyvavimą priimant sprendimus ir juos ịgyvendinant, būtina analizuoti ne tik NVO įtraukimo skatinimo galimybes, bet ir jų kaip piliečių interesams atstovaujančių institucijų atskaitingumo, lygybès, skaidrumo bei etikos principų laikymosi klausimus. Nevyriausybinių organizacijų plètros įstatyme [19], Savivaldybių ir nevyriausybinių organizacijų bendradarbiavimo metodikoje [26] nustatytos šių sektorių sąveikos gairès orientuojasi ị nevyriausybinių organizacijų finansavimą, dalyvavimą teikiant viešąsias paslaugas bei kuriant bendras darbo grupes konkretiems klausimas spręsti ar sutiekiant informaciją apie planuojamas veiklas, tačiau nèra bendrų nuoseklaus bendradarbiavimo principų. Tai atsispindi ir vietos savivaldos Lietuvoje principuose, kurie akcentuoja atsakingumą savivaldos bendruomenei, jos ir atskiru piliečių interesų derinimą, viešumą ir reagavimą i savivaldybės gyventojų nuomonę bei galimybę savivaldybės gyventojams tiesiogiai dalyvauti rengiant ir svarstant sprendimų projektus [20], tačiau bendradarbiavimas su NVO yra tik viena iš savarankiškujų savivaldybès funkcijų, kurios ịgyvendinimą iš dalies nulemia kiekvienos savivaldybès ir jos tarybos požiūris. Esminiai elementai, išskiriami Vietos savivaldybių ir nevyriausybinių organizacijų bendradarbiavimo metodikoje, kuriais siekiama prisidèti prie kiekvienos savivaldybės gero darbo organizavimo, bendradarbiaujant su NVO, yra:

1. kokybiškas sprendimų prièmimas;

2. efektyvus viešųjų finansų panaudojimas; 
3. produktyvus viešosios paskirties patalpų išnaudojimas [26].

Nors jiems igyvendinti vis dar aktualūs tokie trukdžiai kaip: nevyriausybinis sektorius dažnai orientuotas ị finansinę paramą bei dažnai pervertina savo vaidmenị ir jẻgas, jiems stinga bendradarbiavimui reikalingos motyvacijos bei reikalingų žinių ir ịgūžių, o valstybès sektoriui būdingas per didelis noras pasitelkiant NVO išspręsti socialines problemas, todèl keliami neadekvatūs rezultatų kiekybès ir kokybès reikalavimai, stinga pasitikejjimo ir lankstumo bendradarbiaujant su NVO sektoriumi [17]. Kaip teigia autoriai, viešojo sektoriaus institucijos ir administracinis personalas labiau links ịtraukti NVO ị sprendimų prièmimo procesą, tuo tarpu politikai šias organizacijas ir jų dalyvavimą dažnai suvokia kaip galimų problemų ir trukdžių kẻlimą [14], todèl nagrinejjant jų ir savivaldybių sąveiką sprendimų prièmimo procese itin svarbus vaidmuo turètų būti skiriamas savivaldybių tarybų veiklai.

Autoriai, nagrinèjantys pilietinės visuomenès ir jų organizacijų (tarp jų ir NVO) poveikị viešojo sektoriaus sprendimų rengimo, priemimo ir igyvendinimo procese pabrėžia esamos informacijos prieinamumą ir pačių dalyvių norą bei jų galimybes dalyvauti.

\section{1 lentele. Dalyvavimo priimant ir igyvendinant sprendimus aspektai}

\begin{tabular}{|c|c|c|}
\hline R. Dahl & 1994 & $\begin{array}{l}\text { Sprendimų prièmimo alternatyvas nulemia pačių piliečių suvokimo } \\
\text { apie dalyvavimą išugdymas, informacijos jiems suteikimas bei } \\
\text { lygių galimybių dalyvauti priimant sprendimus užtikrinimas. Taip } \\
\text { pat jiems turi būti sudaryta galimybė kontroliuoti darbotvarkę, } \\
\text { sprendžiant, kurie klausimai yra aktualūs }\end{array}$ \\
\hline Z. Wejcman & 2001 & $\begin{array}{l}\text { NVO ịsiliejimas ị valstybės ar savivaldybių funkcijų vykdymą } \\
\text { (daugiausia kalbant apie paslaugų teikimą) kelia šiuos pagrindinius } \\
\text { klausimus: kaip tiksliai suformuluoti užduotis, siekiant užtikrinti } \\
\text { piliečių lūkesčius? Kaip paskirstyti léšas ir užtikrinti įsipareigojimų } \\
\text { vykdymą? Kaip užtikrinti valdžios galimybes operatyviai kore- } \\
\text { guoti vykdomą politiką ir perskirstyti finansavimą. Tačiau kalbant } \\
\text { apskritai apie NVO vaidmenį, pabréžia jų gerąją praktiką ir pasiū- } \\
\text { lymų teikimą }\end{array}$ \\
\hline T. Petrova & 2011 & $\begin{array}{l}\text { Dalyvavimo vietos savivaldos valdyme komponentai planavimo ir } \\
\text { igyvendinimo stadijose yra: } \\
\text { 1. Vertinimas ir gairių nustatymas (poveikis per apklausas, } \\
\text { grupines diskusijas, viešas diskusijas, patariamąsias tarybas } \\
\text { ir pan.) } \\
\text { 2. Strategija ir jos vertinimas (konsultacijos su piliečiais, jų gru- } \\
\text { pėmis ir vietos verslu dèl vietos plètros strategijos) } \\
\text { 3. Projektai ir jų vertinimas (konsultacijos su piliečiais, jų } \\
\text { grupemis ir vietos verslu dèl strategijos igyvendinimo pro- } \\
\text { jektų) } \\
\text { Bendros programos (programų kartu su piliečiais, jų grupèmis } \\
\text { ar vietos verslu igyvendinimas) } \\
\text { İsipareigojimas ištekliais (remimas finansiniais ir nefinan- } \\
\text { siniais ištekliais) }\end{array}$ \\
\hline
\end{tabular}




\begin{tabular}{|l|l|l|}
\hline & & $\begin{array}{l}\text { Dalyvavimas priklauso nuo pačių piliečių aktyvumo bei manymo, } \\
\text { kad i jų nuomonę dalyvaujant sprendimų priemimo procese bus } \\
\text { D. }\end{array}$ \\
$\begin{array}{l}\text { Solomon, } \\
\text { G. S. } \\
\text { Domide }\end{array}$ & 2012 & $\begin{array}{l}\text { svarstyti klausimus bei apie sprendimus, kurių prièmimo metu } \\
\text { jau buvo atsižvelgta ị jų siūlymus. Taip pat, siekiant pasitikèjimo, } \\
\text { turetų būti kuriami jų atstovavimo mechanizmai bei užtikrinama } \\
\text { nuolatinè komunikacija }\end{array}$ \\
\hline
\end{tabular}

Šaltinis: $[11,33,25,30]$

Išskiriami aspektai sutampa su prieš tai S. R. Arnstein ịtraukimo lygmenyse aptartais bruožais, tai yra iškyla abipusiško pasitikejjimo, komunikacijos ir realaus ar tik simbolinio ịtraukimo klausimai, nes tik suteikus prieigą prie informacijos šios organizacijos savaime neigyja galios daryti poveikị sprendimų procesui. Remiantis lentelèje pateiktais dalyvavimo elementais ir tam būtinomis sąlygomis, galima sakyti, jog dalyvavimui priimant ir igyvendinant sprendimus daro poveikị suvokimo apie dalyvavimą išugdymas, informacijos suteikimas bei lygių galimybių dalyvauti priimant sprendimus užtikrinimas. Siekiant nevyriausybinių organizacijų įtraukimo ị ši procesą, vienu esminiu igyvendinimo kriterijumi tampa ataskaitingumas bei viešumas siekiant skaidrumo, o NVO ir savivaldybių sąveiką savivaldybių tarybų sprendimų prièmimo ir įgyvendinimo procese galima suskaidyti į atskirus etapus:

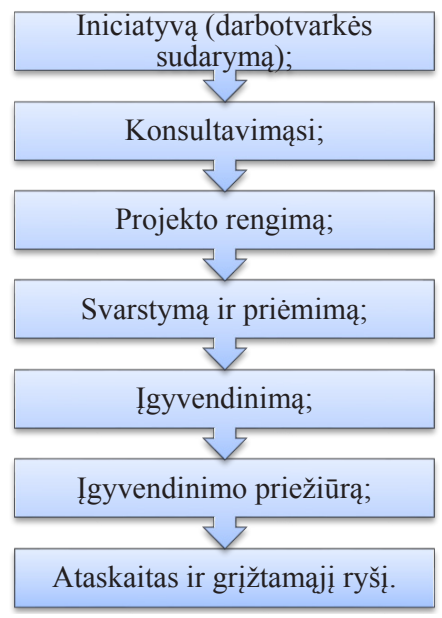

$5 \mathrm{pav}$. Sprendimų prièmimo ir iggyvendinimo procesas savivaldybėje

Šaltinis: sudaryta autorès remiantis [11, 33, 25, 30]

Tačiau, kaip jau minèta, realus sprendimų rengimo procesas panaudojant turimas NVO žinias, patirtị ar / ir pateikiamus įrodymus gali susidurti su natūraliais 
šio proceso apribojimais. Kaip pažymėjo H. A. Simonas, kalbant apie sprendimų prièmimo procesus, pirmiausia reikia atskirti dvi sąvokas: „žinojimą“ ir „,mokẻjimą“, siekiant nustatyti, kas turi žinias, reikalingas sprendimui priimti, ir kaip jie gali dalyvauti šiame procese bei kokị poveikị turèti [29].

M. Sidor teigimu, pagrindinis piliečių ir jų organizacijų įgalinimo tikslas - pagerinti pati sprendimų prièmimo procesą bei pagerinti teikiamas paslaugas, tačiau dabartinè nevyriausybinių organizacijų padètis valstybėse nesuteikia joms kontrolès funkcijos ir turi stipresnị poveikị pačių tikslų igyvendinimui [27]. Nepaisant skatinamo jų ịtraukimo tiek valstybès, tiek savivaldos lygmeniu, apibrěžiant trukdžius, sprendimų rengimo ir prièmimo procese galima išskirti pagrindines ribojančių veiksnių grupes:

1. nenoras keisti esamą situaciją bei „biurokratinė logika“ (kai nesiekiama ieškoti esminių problemos atsiradimo priežasčių, bet pasitikima akivaizdžiais ir anksčiau patikrintais duomenimis);

2. laiko stoka informacijai surinkti;

3. dẻl nesamos viešojo administravimo organizavimo patirties ir teisinio reglamentavimo priimdamos sprendimus institucijos ne visada atsižvelgia ị esamą padètị ir tiksliai suvokia esamus faktus bei ịrodymus [21, p. 82].

Kaip pažymi kiti autoriai, sprendimų priėmimo kokybei labai svarbus informacijos valdymas, jos naudojimas ir interpretavimas. Sprendimų prièmimo procese sprendimų rengejai dažnai informacijos apdorojimą suvokia kaip informacijos filtravimo procesą prieš priimant aukščiausio lygmens sprendimus, tad sprendimus rengiančiose biurokratinèse struktūrose atsiranda galimybẻ blokuoti, atrinkti informacijos srautus, taip darant poveikị būsimų sprendimų poveikiui ir rezultatams [8, p. 18]. Todèl siekiant nustatyti, kas yra pagrindiniai dalyviai, kokia komunikacijos / sąveikos tarp skirtingų veikejų bei jų grupių priimant ir ịgyvendinant sprendimus kokybė, išskiriami politine valia ir ịrodymais grịsti sprendimai. Siekiant identifikuoti jų pagrindą, dalyvius (savivaldybės, nevyriausybinès organizacijos, pilietinè visuomenè bei kitos interesų grupès) bei kokie trukdžiai dažniausiai riboja nevyriausybinių organizacijų dalyvavimą šiame procese, galima išskirti tris atskiras grupes klausimų, apibūdinančių šio proceso dalyvių tarpusavio ryšius ir jiems poveiki darančius veiksnius: 
2 lentelè. Savivaldybės sprendimų prièmimo ir igyvendinimo proceso dalyvių sąveika

\begin{tabular}{|c|c|c|}
\hline Piliečių ir NVO sąveika & $\begin{array}{c}\text { NVO ir savivaldybės ir jos } \\
\text { tarybos sąveika }\end{array}$ & $\begin{array}{l}\text { NVO sąveika su kitomis } \\
\text { interesų grupėmis }\end{array}$ \\
\hline $\begin{array}{l}\text { Kieno interesams ir } \\
\text { kokiomis teisèmis } \\
\text { nevyriausybinès } \\
\text { organizacijos atstovauja? } \\
\text { - Ar jos turi reikalingus } \\
\text { gebėjimus atstovauti } \\
\text { piliečių ar savo narių } \\
\text { interesams? }\end{array}$ & $\begin{array}{l}\text { Kaip nevyriausybinès } \\
\text { organizacijos patenka } \\
\text { ị sprendimų prièmimo } \\
\text { ir igyvendinimo } \\
\text { mechanizmą? } \\
\text { - Ar savivaldybės taryba, } \\
\text { kaip sprendimus } \\
\text { priimantis subjektas, } \\
\text { linkusi bendradarbiauti } \\
\text { ir atsižvelgti ị interesų } \\
\text { grupes? } \\
\text { Ar savivaldybėje yra } \\
\text { numatyti / veikia } \\
\text { informavimo bei } \\
\text { grị̌ztamojo ryšio } \\
\text { mechanizmai? }\end{array}$ & $\begin{array}{l}\text { - Ar nevyriausybinè } \\
\text { organizacija linkusi } \\
\text { bendradarbiauti su } \\
\text { kitomis organizacijomis? }\end{array}$ \\
\hline \multicolumn{3}{|c|}{ Bendri aspektai: } \\
\hline \multicolumn{3}{|c|}{$\begin{array}{c}\text { - Koks sprendimų priemimo ir igyvendinimo išorinis reglamentavimas? } \\
\qquad \text { Koks neformalaus bendradarbiavimo vaidmuo? } \\
\text { - Ar NVO konkuruoja su kitais dalyviais (tarp jų ir su pačia savivaldybe) dèl ribotų } \\
\text { išteklių (pvz., finansinès paramos) }\end{array}$} \\
\hline
\end{tabular}

Šaltinis: sudaryta autorès

Apibendrinant nevyriausybinių organizacijų poveikị sprendimų prièmimui ir igyvendinimui vietos savivaldos lygmeniu, taip pat išskirtinas ir pačių nevyriausybinių organizacijų indèlis, tai yra, siekdamos užsitikrinti visuomenès palaikymą, nevyriausybinès organizacijos itin daug dẻmesio turi teikti savo misijos visuomenei pristatymui, informacijos sklaidai ir teisinio reglamentavimo tobulinimui. Siekiant jų, kaip pilietinei visuomenei atstovaujančių institucijų įtraukimo ir igalinimo mechanizmų suformavimo, pirmiausia turètų būti apibréžta ne tik šio sektoriaus specifika, bet ir jo atskaitomybė ir atskaitingumas, taip siekiant realaus šio sektoriaus veiklos, turinčios poveikị visai visuomenei, monitoringo. O šių klausimų analizė leistų apibréžti, kokia išorinė bei vidinè aplinka daro poveikị sprendimų priẻmimo ir igyvendinimo procesui kiekvienu iš tiriamų atvejų, atsižvelgiant $i \mathfrak{\text { jo }}$ jo specifines charakteristikas, bei leistų numatyti nevyriausybinių organizacijų igalinimo ir ịtraukimo i č și procesą prielaidas. 


\section{Išvados}

1. Nevyriausybinès organizacijos gali būti suvokiamos ir kaip pilietinès visuomenès veiklos rezultatas, ir priemonė jai igyvendinti savo tikslus vienu metu. Šios organizacijos užima išskirtinę padètį kitų sektorių atžvilgiu ir dažnai ịvardijamos kaip tarpininkas tarp privataus ir viešojo sektoriaus, nes linkusios su jomis bendradarbiauti viešojo sektoriaus institucijos skatinamos tapti skaidresnès, atskaitingesnès bei atliepesnès visuomenès poreikiams, tuo tarpu visuomenè linkusi labiau pasitikèti šiomis institucijomis ir jų veikla.

2. Analizuojant sprendimų prièmimo ir ígyvendinimo procesą Lietuvos savivaldybėse, ịprastai kalbama apie savivaldybių tarybų sprendimus bei apimami visi sprendimo valdymo etapai: inicijavimas, darbotvarkès sudarymas, konsultavimasis su suinteresuotųjų grupèmis, projektų rengimas, jų svarstymas bei prièmimas, priimto sprendimo ịgyvendinimas, priežiūra, grįžtamasis ryšys bei jo poveikio analizè. Išskiriant atskirus proceso etapus, kiekviename iš jų akcentuojamas galimas įrodymais arba politine valia grịstų sprendimų pagrindimas, taip siekiant pabrèžti ryši tarp svarbiausių proceso veikèjų bei jų veiklos tikslų.

3. Nevyriausybinių organizacijų galimybėms dalyvauti savivaldybių sprendimų prièmimo ir igyvendinimo procese daro poveikị ne tik esamas reglamentavimas bei suformuoti atstovavimo mechanizmai, bet ir tokie veiksniai kaip nevyriausybinių organizacijų ir savivaldybès (bei jos tarybos) gebejjimas bendradarbiauti, jų tarpusavio pasitikejjimas, santykis su piliečiais, kitomis nevyriausybinėmis organizacijomis bei interesų grupėmis. Taip pat tai, ar šios institucijos suvokia ir jaučia poreikị bendradarbiauti sprendimų prièmimo ir ịgyvendinimo proceso metu, tad vienas pagrindinių nevyriausybinių organizacijų įtraukimą į sprendimų prièmimo ir ịgyvendinimo procesą skatinančių veiksnių - pačių organizacijų savęs, kaip visuomenès interesams atstovaujančių ir jai atskaitingų organizacijų suvokimas ir pozicionavimas, taip užsitikrinant kitų grupių paramą.

\section{Literatūra}

1. Arimavičiūtè, M. Strateginio planavimo tobulinimas kaimiškose savivaldybèse, remiantis užsienio šlių patirtimi. Ekonomika ir vadyba: aktualijos ir perspektyvos. 2011, T. 4, Nr. 24, p. 21-30.

2. Arnstein. S. R. A Ladder of Citizen Participation. Journal of the American Institute of Planners. 1969, Vol. 35, No. 4, p. 216-224.

3. Banks, N., Hulme D. The Role of NGOs and Civil Society in Development and Poverty Reduction. BWPI Working Paper, 2012, p. 24. http://www.bwpi.manchester.ac.uk/ resources/Working-Papers/bwpi-wp-17112.pdf

4. Bileišis, M., Guogis, A., Šilinskytè, A. Government-Community Conflict: the Lithuanian Public Governance Challenge. Viešoji politika ir administravimas. 2014, T. 13, Nr. 1, p. 30. 
5. Bovaird, T., Loeffler, E. We're all in this together: harnessing user and community coproduction of public outcomes. Chapter 4. University of Birmingham, Institute of Local Government Studies, 2013.

6. Brandsen, T., Verschuere, B., Pestoff, V. Co-production: The State of the Art in Research and the Future Agenda. VOLUNTAS: International Journal of Voluntary and Nonprofit Organizations. 2012, Vol. 23 No. 4, p. 1083-1101.

7. Bučaitè, J., Ambotaitè-Mazeliauskienè, I. Instituciniai tinklai ir socialinis pasitikèjimas savivaldybės ir nevyriausybinių organizacijų sąveikoje. Viešoji politika ir administravimas. 2005, Nr. 13, p. 74-82.

8. Buškevičiūtè, J., Raipa, A. Sprendimai šiuolaikinio viešojo valdymo evoliucijoje. Viešoji politika ir administravimas. 2011, T. 10, Nr. 1, p. 17-26.

9. Crane, A. From governance to Governance: On Blurring Boundaries. Journal of Business Ethics. 2010, No. 94, p. 17-19

10. CSO Sustainability Index for Central and Eastern Europe and Eurasia, 16th edition, 2013, p. 25. http://www.usaid.gov/sites/default/files/documents/1863/2012CSOSI_0.pdf

11. Dahl, R. A. A Democratic Dilemma: System Effectiveness versus Citizen Participation. Political Science Quarterly.1994, Vol. 109, No. 1, p. 31.

12. Fairholm, M. R. Why a Rational Move Toward "Governance" May Destroy the Soul of Public Administration: Or Why Governance Isn’t Concerned with Government Anymore. Selected Papers from the Fifth Transatlantic Dialogue on Public Administration. Ed. T. Brandsen, M. Holzer 2009, p. 9

13. Fisher, W. F. Doing Good? The Politics and Antipolitics of NGO Practices. Annual Review of Anthropology. 1997, Vol. 26, p. 441.

14. Grigaliūnaitė J., Mačiukaitė-Žvinienè, S. Looking for Civil Participation in the Baltic States: Non - Governmental Sector. Viešoji politika ir administravimas. 2006, Nr. 17, p. $115-122$.

15. Guogis, A., Gudelis, D. Viešojo administravimo ir verslo vadybos integracija ir perspektyvos: viešojo ir privataus sektorių sąveikos modelis. Viešoji politika ir administravimas. 2009, Nr. 28, p. 23-28.

16. Holder, C. Devolving Power tu Sub-State Groups: Some Worries About the Worries. The Monist. 2012, Vol. 95, No.1, p. 89-90.

17. Kučikas, A. Didieji lūkesčiai. Savivaldybių ir nevyriausybinių organizaciju partnerystè. Vilnius: Nevyriausybinių organizacijų informacijos ir paramos centras, 2001, p. 10-11.

18. Lewis, D. Management of Non-Governmental organizations: Catalysts, Partners and Implementors. Routledge, 2000, p. 68-69. http://site.ebrary.com/lib/mrulibrary/ Doc? $\mathrm{id}=2002722 \& p p g=171$

19. Lietuvos Respublikos nevyriausybinių organizacijų plètros ịstatymas, 2013 gruodžio 19 d., Nr. XII-717.

20. Lietuvos Respublikos vietos savivaldos įstatymas (aktuali redakcija), 2014 gegužès 15 d., Nr. I-533.

21. Mikulskienè, B. İrodymais grịstos politikos paraiškos Lietuvos viešojo valdymo institucijose. Jurisprudencija. 2008, T.5, Nr. 107, p. 82.

22. Millar, H. Comparing accountability relationships between governments and non-state actors in Canadian and European international development policy, Canadian Public Administration. The Institute of Public Administration of Canada. 2013, V. 56, Nr. 2, p. 252-269. 
23. Osborne, S. P., McLaughlin, K. The Cross-Cutting Review of the Voluntary Sector: Where Next for Local Government- Voluntary Sector Relationships? Regional Studies. Routledge. 2004, Vol. 38.5, p. 573-582.

24. Pestoff, V. Co-production, New Public Governance and Third Sector Social Services in Europe. Ciencias Sociais Unisinos, Sao Leopoldo. 2011, Vol. 47, No. 1, p. 15-24.

25. Petrova, T., Citizen Participation in Local Governance in Eastern Europe: Rediscovering a Strength of Civil Society in the Post-Socialist World? Europe-Asia Studies. Routledge. 2011, Vol. 63(5) , p. 757-787.

26. Savivaldybių ir nevyriausybinių organizacijų bendradarbiavimo metodika. Nevyriausybinių organizacijų informacijos ir paramos centras, 2013. http://www.3 sektorius.lt/ docs/Knygelepilna_2013-12-18_11:06:27.pdf

27. Sidor M., The Process of Enhancing Citizens' Participation in Local Government in Poland. Socialiniai tyrimai. 2012, Nr. 3 (28), p. 87-97.

28. Šiliauskas, S. Pilietinès visuomenès ir pilietiškumo diskursai modernioje demokratijos refleksijoje. Viešoji politika ir administravimas. 2005, Nr. 11, p. 26.

29. Simon, H. A. Bounded Rationality and Organizational Learning. Organizational Science. 1991, Vol. 2, No. 1, (Reprinted by Reflections, Volume 1, Number 2, p. 17-27).

30. Solomon, A. D., Domide, G. S. Citizen Right to Information - Beneficiary of Administration Reform. International Conference of Scientific Paper Afasas, Brasov (Romania), 2012, 24-26 May.

31. Steets, J. Accountability in Public Policy Partnerships. Palgrave Macmillan, 2010, p. 2-14.

32. Wejcmanas, Z. Kaip kurti efektyvią nevyriausybinių organizacijų partnerystę. Savivaldybiu ir nevyriausybiniu organizaciju partnerysté. Vilnius: Nevyriausybiniu organizacijų informacijos ir paramos centras, 2001, p. 60.

33. Wejcmanas, Z. Vietos valdžios institucijų bendradarbiavimas su nevyriausybinèmis organizacijomis - galimybės ir barjerai. Savivaldybiu ir nevyriausybiniu organizaciju partnerystė. Vilnius: Nevyriausybinių organizacijų informacijos ir paramos centras, 2001, p. 13-18.

\title{
Aušra Šilinskytė \\ Interaction between Non-governmental Organizations and Municipalities in Lithuania: Theoretical Aspects of the Decision-making and Implementation Process
}

\begin{abstract}
The paper is focused on the discussion about the role of non-governmental organizations during the decision-making process in local governance and what factors influence it. To achieve this, the following steps have been made: first, the concept of non-governmental organizations and their relationship with civil society was analyzed, then possible variations of relationship between non-governmental organizations and their impact to the public sector was described. In the last part of the paper, the stages of the decision-making and implementation process in the municipality were analyzed and theoretical aspects of enabling NGOs were discussed. The analyses showed that the decision-making and implementation processes depend on the understanding of the need to cooperate, the ability of both subjects to work together, their relationship with citizens and other interest groups.
\end{abstract}


Aušra Šilinskyte - Mykolo Romerio universiteto Viešojo administravimo instituto doktorante E. paštas: ausrine@mruni.eu

Aušra Šilinskytè, Mykolas Romeris University, Institute of Public Administration, PhD student. E-mail: ausrine@mruni.eu

Straipsnis įteiktas redakcijai 2015 m. sausio mèn.; recenzuotas; parengtas spausdinti birželio mèn. 